\title{
The Influence of Computer-Based Learning Media Tutorials on Students' Spatial Ability in Mathematics
}

\author{
Kamid $^{1(*)}$, Sofnidar ${ }^{2}$, Wardi Syafmen ${ }^{3}$, Mujahidawati $^{4}$, Roseli Theis ${ }^{5}$, \\ Khairul Anwar ${ }^{6}$ \\ 1,2,3,4,5,6 Faculty of Teaching and Education, Universitas Jambi, Jl. Lintas Jambi-Muaro \\ Bulian, 36361, Indonesia
}

Received: August 10, 2020

Revised: January 7, 2021

Accepted: January 9, 2021

\begin{abstract}
In 21 st century learning students is required to be more active in learning than teachers, therefore this study aims to determine whether there is an influence between computer-based learning media tutorials and students' spatial abilities in mathematics. Using quantitative descriptive. The number of samples were 240 students from SMP 11 Jambi City using purposive sampling technique. Data were then analyzed helped by SPSS 21 application to find descriptive statistics in the form of mean, min, max, and category as well as inferential statistics using simple regression. The results obtained in this study are dominant in both the spatial abilities of students in mathematics. With this reinforced by the existence of a relationship and influence between computer-based learning media tutorials with students' spatial abilities in mathematics as seen from the sig value below 0.025 , which is 0.016 and has a contribution of $72.6 \%$.
\end{abstract}

Keywords: Spatial Ability, Mathematics, Learning Media

(*) Corresponding Author:

How to Cite: Kamid, et al. (2020). The influence of computer-based learning media tutorials on students's spatial ability in mathematics. Jurnal Teknologi Pendidikan, 22 (3): 159-166. http://dx.doi.org/10.21009/jtp.v22i3.16536

\section{INTRODUCTION}

The need for the 21 st century in the curriculum of educational institutions is oriented to create productive, creative, innovative, and effective generations through the integration of attitudes, abilities and knowledge with life skills (Andrini, 2016; Kabeel and Eisa, 2016; Taghva et al, 2014). Therefore, educational institutions in the country set competence as the goal of the curriculum goals (Pantic \& Wubbels, 2012; Unlu, 2018). In addition, lecturer education practitioners agree that teacher education aims to educate high-quality teachers who will be successfully integrated into the education system (Ezer, Gilat \& Sagee, 2010; Boonjeam, Tesaputa, \& Sri-ampai, 2017; Leonard \& Wibawa, 2020). It is hoped that the global competence of school teachers in the future will include the knowledge base, skills, and attitudes they need to effectively carry out their professional duties in school and function profitably in a changing and interdependent society (Sinagatullin, 2019), especially in mathematics.

In the students' view, they must have a good attitude. The student must also have good abilities in him. One of those abilities is spatial ability. The spatial ability it is the individual's ability to see and imagine space objects by simply making pictures of these space objects on paper. The concept of spatial thinking is quite interesting to discuss considering that many previous studies have found that children find it difficult to understand objects or geometric shapes. According to Jelatu \& Ardana (2018), spatial 
ability in learning mathematics is one of the factors that affect student learning success. There are still many geometric problems that require visualization for problem solving and in general, students find it difficult to construct geometric spatial shapes (Wulandari, 2019). Spatial ability in mathematics learning is very important, given that many students find it difficult to understand objects or geometric figures, so that teachers are required to pay more than enough attention so that spatial skills are taught in accordance with the mandate of the curriculum.

To solve problems in prism and pyramid material, one must have spatial ability because there are many problem materials that cannot be realized in actual form or shape. Therefore, they are only visualized or described in two-dimensional form. This threedimensional visualization into two-dimensional forms requires students' imagination and abstraction, so it is often confusing for them. Spatial ability (spatial view), namely (1) the ability to perceive, namely to capture and understand something through the five senses, (2) the ability of the eye, especially color and space, (3) the ability to transform, namely transforming what the eye catches into other forms, for example observing, recording, interpreting in mind then pouring the recordings and interpretations into the form of paintings, sketches and collages (Hariatuti, Anita \& Setiawan, 2018).

Pranawestu, Kharis, \& Mariani (2012), an alternative to foster spatial skills is by using mathematics learning media. The results of observations at SMP N 11 Jambi City, only a few mathematics teachers use media in the learning process in class. The learning media are in the form of concrete objects. With the media of concrete objects, learning materials for space structures can be conveyed by showing real objects from the shapes studied, such as cubes, blocks, etc. However, with this media, the students' attention was not fully focused on the media of concrete objects because the media that was demonstrated only amounted to one and was held by the teacher.

Because of these weaknesses, of course, a media other than concrete objects is needed. Many media that can be utilized include the Macromedia Director MX program combined with computer-based learning tutorial models. MX's Macromedia director program excels in making learning media because it's a director called a director. With the advantage of being able to import various media formats such as Adobe Photoshop, Wave editor, Flash, Quicktime and others, Macromedia Director MX is very suitable for learning media creation projects.

Rusman (2018) states that learning media is a messenger technology that can be used for learning purposes; learning media is a physical means for delivering subject matter; Learning media is a means of communication in the form of print and listening views including hardware technology. The use of computer technology as a learning medium has contributed a lot to the learning process. One of them is by simplifying and clarifying such diverse material and providing concrete examples (Astalini et al, 2019; Darmaji et al 2019; Asrial et al, 2020; Maison et al, 2020).

Hendra (2017) argues that the use of computers in learning allows the learning process to take place individually (individual learning) by fostering independence in the learning process so that students will experience a much more meaningful process compared to conventional learning. Teachers can take advantage of computer technology as interactive learning media, because with this learning media the teacher can directly visualize prisms and pyramids. By using computer technology, especially computer-based learning with the Tutorial model, it is possible for each concept to be conveyed in a textual or visual form accompanied by an evaluation so that students' understanding of the material presented can be measured at the time of learning.

Tutorial model computer-based learning is a learning program used in the learning process by using software in the form of a computer program that contains subject matter and practice questions. The purpose of computer-based tutorial is to 
provide "satisfaction" or complete understanding (mastery learning) to students regarding the material/subject matter they are learning (Admaja, Kuswandi \& Soepriyanto, 2019). According to Sutarman (2016), through computer-based tutorial/learning, computers as tutors are oriented towards efforts to build student behavior through the use of computers. In simple terms, the PfP operating patterns are as follows: (1) the computer presents material, (2) students respond, (3) students' responses are evaluated by the computer with an orientation towards the student's direction in taking the next achievement, and (4) continue or repeat the previous stage.

Therefore, this study aims to determine whether the tutorial-based learning media has an influence on students' spatial abilities. With the following questions: 1) How do students have spatial abilities in mathematics? And 2) Is there any influence between the tutorial-based learning media and the students' spatial abilities in mathematics?

\section{METHODS}

This research is a mixed study with an explanatory sequential design. Explanatory sequential is a mixed research design, which begins with quantitative data collection, then continues with qualitative data (Creswell, 2012; Kerlinger, 2014). This study involved 240 eighth grade students of 11 junior high schools in Jambi City. The subject is obtained using purposive sampling technique. Sampling was based on the criteria set by the researcher (Cohen, Manion, \& Morisson, 2007). The criteria are junior high school students grade VIII and accredited A.

The instrument in this study used semi-structured tests and interviews. The test used in this study was an essay of 5 questions to see the students' spatial abilities in mathematics, the essay instrument has been validated by experts and has been declared fit for use. For the calculation, each correct question is worth 20 so that the maximum score obtained is 100 . Then an interview is conducted to strengthen the quantitative results, the type of interview used is semi-open.

Where the categories in this study can be seen in table 1

Table 1. Students' spatial abilities in mathematics

\begin{tabular}{lc}
\hline \multirow{2}{*}{ Category } & Interval \\
\cline { 2 - 2 } & Spatial Abilities \\
\hline Very Not Good & $00.0-20.0$ \\
Not Good & $20.1-40.0$ \\
Enough & $40.1-60.0$ \\
Good & $60.1-80.0$ \\
Very Good & $80.1-100.0$ \\
\hline
\end{tabular}

During data collection, the first activity that must be done is to select students based on the categories provided by the researcher, the test score is then processed using SPSS 21 application data to see descriptive statistics, in the form of, the mean, min, max, percentage, and category of students and see if there is an impact between the two variables.

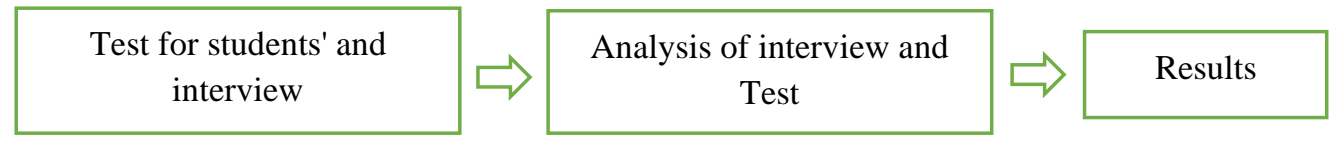

Figure 1. Data Collection 
All data were obtained from tests conducted and interview data collected and calculated which were assisted with the SPSS 21 application. Descriptive statistics are provided to calculate the frequency, percentage, average, min, and max sample (Cohen, Manion, \& Morisson, 2007). In this study, quantitative data were analyzed using parametric statistics from simple regression to determine whether there was an impact between computer-based instructional media tutorial models and students' spatial abilities in mathematics. This study uses SPSS 21 at a significance level of 0.025 .

\section{RESULTS AND DISCUSSION}

\section{Results}

\section{Problem solving skill}

The results of the test given and the results obtained using the SPSS 21 application can be seen in the table 2 .

Table 2.The results of the test aimed at seeing the students' problem solving abilities

\begin{tabular}{|c|c|c|c|c|c|c|}
\hline \multicolumn{3}{|c|}{ Classification } & \multirow{2}{*}{ Mean } & \multirow{2}{*}{$\operatorname{Max}$} & \multirow{2}{*}{ Mix } & \multirow{2}{*}{$\%$} \\
\hline Range & Category & Total & & & & \\
\hline $00.0-20.0$ & Not very good & 0 & & & & 0.0 \\
\hline $20.1-40.0$ & Not good & 4 & & & & 1.7 \\
\hline $40.1-60.0$ & Enough & 23 & 75.5 & 80 & 40 & 9.6 \\
\hline $60.1-80.0$ & Good & 172 & & & & 71.6 \\
\hline $80.1-100.0$ & Very good & 41 & & & & 17.1 \\
\hline TOTAL & & 240 & & & & 100 \\
\hline
\end{tabular}

From table 2, which came from 240 respondents from the junior high school in Jambi after they were obtained and the results obtained using the SPSS 21 application program, the spatial ability of students in learning mathematics has a good dominant result, with a percentage of $71.6 \%$ For 172 students out of a total of 240 students, it is very good at $17.1 \%$ for 41 students out of a total of 240 students, $9.6 \%$ enough for 23 students out of a total of 240 students, and not good for $1.7 \%$ for 4 students out of a total of 240 students. From 240 students, the mean score was 75.5., The maximum score was 80 , and the minimum score was 40 .

The results of the test analysis given to students in table 2 have a dominant good spatial ability of $71.6 \%$ (172 of 240) students in mathematics. This ability is shown by being able to understand in learning because it has good spatial abilities. This can also be seen from the results of interviews that have been conducted.

"When a math lesson is underway using computer-based tutorials, what do you feel?"

"I am more enthusiastic in participating in learning"

"Why is that?"

"Because teachers who teach use interesting learning media, so I am excited about learning"

"What benefits can you get after you carry out learning using computer-based tutorials?"

"I am able to mention the properties of prism and pyramid space shapes, besides that, I can visualize the prism and pyramid space shapes then operate these numbers into 
formulas, and be able to draw prism and pyramid spatial shapes according to mathematical concepts"

\section{Influence}

For the results of the influence of computer-based learning media Tutorial Model with students' spatial abilities can be seen in table 3 .

Table 3. The influence of the Computer Tutorial Model learning media on students' spatial abilities

\begin{tabular}{|c|c|c|c|c|c|}
\hline \multirow[t]{2}{*}{ Variable } & \multicolumn{2}{|c|}{$\begin{array}{l}\text { Unstandardized } \\
\text { Coefficients }\end{array}$} & \multirow{2}{*}{$\begin{array}{c}\text { Standardized } \\
\text { Coefficients } \\
\text { Beta }\end{array}$} & \multirow[t]{2}{*}{$\mathbf{t}$} & \multirow[t]{2}{*}{ sig. } \\
\hline & B & Std. Error & & & \\
\hline 1 (Constant) & 13.452 & 3.151 & & 4.541 & .000 \\
\hline Spatial Abilities & .229 & .124 & .123 & 1.415 & .016 \\
\hline
\end{tabular}

From table 3, it can be seen the results of a simple regression test found that the regression equation is $\mathrm{Y}=13.452+0.229 \mathrm{X}$. for the number of contributions from media pembelajaran berbasis Komputer Model Tutorial on kemampuan spasial siswa can be seen in table 4.

Table 4. Contribution of computer-based learning media Tutorial Model on students' spatial abilities

\begin{tabular}{ccccc}
\hline Model & R & R square & $\begin{array}{c}\text { Adjust R } \\
\text { Square }\end{array}$ & $\begin{array}{c}\text { Std. Error of the } \\
\text { Estimate }\end{array}$ \\
\hline 1 & .809 & .726 & .712 & 2.824 \\
\hline
\end{tabular}

The result of a simple regression analysis shows that the coefficient of determination is (R2) 0.726. This means that the contribution of the Tutorial Model Computer-based learning media to students' spatial abilities in mathematics is $72.6 \%$, while the remaining $27.4 \%$ is influenced by other variables.

\section{Discussion}

Based on the results obtained from quantitative and qualitative data, it was found that students had high interest and enthusiasm for learning because they used interactive learning media. In addition, students are able to mention the properties of prism and pyramid spatial shapes, can visualize prism and pyramid spatial shapes, then operate these numbers into formulas, and are able to draw prism and pyramid spatial shapes according to mathematical concepts.

Spatial abilities are abilities that include the ability to think in images, as well as the ability to absorb, change and recreate various aspects of the visual world. Spatial abilities are very important to be improved, this is based on the results of research by the National Academy of Scince (Syahputra, 2013) which states that every student must strive to develop skills and spatial sensing which are very useful in understanding the relationships and properties in geometry to solve mathematical problems and problems in everyday life. This is reinforced by Giaquinto's opinion which states that the perception of an object or image can be influenced in an extreme way by the object's orientation. So that you can recognize an object/image precisely requires spatial ability (Syahputra, 2013). Visual-spatial intelligence relates to the ability to perceive color, direction, space 
accurately. Musfiroh As stated by Armstrong, students who are intelligent in spatial visuals have a sensitivity to color, lines, forms, space and buildings (Tambunan, 2010). According to McGee (1979), mathematic ability is a combination of general intelligence, visual imagery, the ability to observe numbers, spatial configurations and store configurations as mental patterns. In spatial abilities, it is necessary to have left-right understanding, understanding perspective, geometric shapes, connecting spatial concepts with numbers, the ability to transform mental images from visual images. These factors are also needed in learning Mathematics.

Therefore, it is very important to use effective learning media in learning. One of them is computer tutorial based learning media. This is in accordance with these conditions in accordance with research conducted by Edi Syahputra (2011), which concluded that learning geometry using computer assistance can improve students' spatial abilities. Kusumah (2011) states that a computer with a good software design can present repetitive and dynamic presentations that are not found in other media. In addition, computers can be used to overcome individual differences, teach concepts, and stimulate student learning. As a learning medium, computers not only function as carriers of new nuances, but also play a role in developing students' talents, interests, and abilities in mathematics.

\section{CONCLUSION}

Based on the results and the discussion that has been described, the dominant results obtained both from the spatial ability of students in mathematics lessons using computer-based tutorials. Therefore, by using new learning innovations, one of which is using tutorial, computer-based learning media, it can improve students 'spatial abilities; students' spatial abilities are abilities that should be owned and developed by students. This is also supported by the existence of a relationship between computer-based learning media tutorials with students' spatial abilities in mathematics and there is an influence between these two variables with a contribution of $72.6 \%$. According to the results, it is recommended that students need to be given the opportunity to do direct learning and teachers should carry out innovative learning.

\section{REFERENCES}

Admaja, A. M., Kuswandi, D., \& Soepriyanto, Y. (2019). Pengembangan multimedia tutorial untuk guru dalam mengembangkan software tes berbasis komputer. JINOTEP (Jurnal Inovasi dan Teknologi Pembelajaran): Kajian dan Riset Dalam Teknologi Pembelajaran, 5(2), 63-68.

Andrini, V. S. (2016). The effectiveness of inquiry learning method to enhance students' learning outcome: A theoritical and empirical review. Journal of Education and Practice, 7(3), 38-42.

Astalini., Darmaji., Kurniawan, W., Khairul, A., \& Kurniawan, D. A. (2019) Effectivenes of using e-module and e-assessment. International Journal of Interactive Mobile (IJIM), 13(9), 21-39.

Asrial., Syahrial., Kurniawan, D. A., Perdana, R., Nugroho, P, (2019). Supporting technology 4.0: Ethnoconstructivist multimedia for elementary schools. International Journal of Online and Biomedical Engineering (iJOE), 15(9), 4-15

Boonjeam W., Tesaputa K., \& Sri-ampai A (2017). Program development for primary school teachers' critical thinking. International Education Studies, 10(2), 131-138. 
Cohen, L., Manion, L., \& Morrison, K. (2005). Research Methods In Education. Routledge.

Creswell, John W. 2012. Educational Research: Planning, Conducting, and Evaluating Quantitative And Qualitative Research. New York: Pearson

Darmaji., Astalini., D. A. Kurniawan., H. Parasdila., Irdianti., S. Hadijah., R. Perdana. (2019). Practicum guide: Basic physics based of science process skills. Humanities \& Social Science Reviews, 7(4), 151-160

Ezer, H., Gilat, I \& Sagee, R. (2010). Perception of teacher education and professional identity among novice teachers. European Journal of Teacher Education, 33(4), 391-404. 10.1080/02619768.2010.504949

Hariastuti, R. M., Anita, D., \& Setiawan, M. A. (2018). Pengembangan media GEO-SD (geometri sketsa dimensi) sebagai penunjang kemampuan visual spasial. AKSIOMA: Jurnal Program Studi Pendidikan Matematika, 7(1), 10-18.

Hendra, H. (2017). Peningkatan hasil belajar matematika siswa dengan media komputer model tutorial interaktif pada materi trigonometri kelas X-6. Jurnal Cendekia: Jurnal Pendidikan Matematika, 1(2), 41-50.

Jelatu, S., \& Ardana, I. M. (2018). Pengaruh penggunaan media geogebra terhadap pemahaman konsep geometri ditinjau dari kemampuan spasial siswa. Jurnal Pendidikan dan Kebudayaan Missio, 10(2), 162-171.

Kabeel, A. R., \& Eisa, S. A.-M. (2016). The correlation of critical thinking disposition and approaches to learning among baccalaureate nursing student. Journal of Education and Practice, 7(32), 91-103.

Kerlinger, F. N. (2014). Foundations of behavioral research. Yogyakarta: Gadjah Mada University Press.

Kusumah, Y.S. (2011). Aplikasi teknologi informasi dan komunikasi dalam pembelajaran matematika untuk meningkatkan kemampuan matematis siswa. Makalah disajikan dalam Kegiatan Pelatihan Aplikasi Teknologi dan Komunikasi dalam Pembelajaran Matematika

Leonard \& Wibawa, B. (2020). Development of teacher research competency training system in Indonesia: A need analysis. Universal Journal of Educational Research, 8 (5), 2064-2070.

Maison., Astalini., Kurniawan, D. A., Perdana, R., Anggraini, L. (2019). The phenomenon of physicology senior high school education: Relationship of students' attitudes towards physics, learning style, motivation. Universal Journal of Educational Research, 7(10), 2199-2207.

McGee, M. F. (1979). Human spatial ability: Psychometric studies and environment: Genetic, hormonal, and neurological influences. Psychological Bulletin, 5, 887902.

Pantic, N \& Wubbels, T. (2012). Competence-based teacher eduation: A change from didaktik to curriculum culture. Journal of Curriculum Studies, 44 (1). 61-87, DOI: 10.1080/00220272.2011.620633.

Pranawestu, A., Kharis, M., \& Mariani, S. (2012). Keefektifan problem-based learning berbantuan cabri $3 \mathrm{~d}$ berbasis karakter terhadap kemampuan spasial. Unnes Journal of Mathematics Education, 1(2).

Rusman, R. (2018). Implementasi model pembelajaran berbasis komputer untuk meningkatkan kompetensi siswa pada mata pelajaran matematika di SMK. Jurnal Teknodik, 21(3), 113-139.

Signagatullin, I. M. (2019). Developing preservice elementary teachers' global competence. International Journal of Educational, 28(1), 48-62, DOI: $10.1177 / 1056787918824193$ 
Sutarman, A. (2016). Pemanfaatan pembelajaran berbasis komputer model cd interaktif tutorial untuk meningkatkan hasil belajar. Jurnal Penelitian dan Pembelajaran IPA, 2(1), 81-98.

Syahputra, E. (2013). Peningkatan kemampuan spasial siswa melalui penerapan pembelajaran matematika realistik. Jurnal Cakrawala Pendidikan, 3(3).

Taghva, F., Rezael, N., Ghaderi, J., \& Taghva, R. (2014). Studying the relationship between critical thinking skills and students' educational achievement (Eghlid Universities as case study). International Letters of Social and Humanistic Sciences, 25, 18-25. doi:10.18052/www.scipress.com/ILSHS.25.18

Tambunan, S. M. (2010). Hubungan antara kemampuan spasial dengan prestasi belajar matematika. Hubs-Asia, 10(1).

Unlu, Sahika. (2018). Curriculum development study for teacher education supporting critical thinking. Eurasia Journal Educational Research, 76, 165-186.

Wulandari, S. (2019). Kemampuan spasial dalam pengkonstruksian jaring-jaring kubus dan balok. Jurnal Edukasi Matematika dan Sains, 7(1), 30-36. 